\title{
PROFIL KEMAMPUAN KOMUNIKASI MATEMATIS SISWA KELAS IX DALAM MENYELESAIKAN MASALAH MATEMATIKA MATERI STATISTIKA BERDASARKAN GAYA BELAJAR
}

\author{
Maya Safitri ${ }^{1}$, Umi Farihah ${ }^{2}$ \\ ${ }^{1,2}$ Institut Agama Islam Negeri Jember \\ mayasafitri106@gmail.com ${ }^{1}$, u_farihah@yahoo.com²
}

\begin{abstract}
ABSTRAK
Penelitian ini dilatarbelakangi oleh sebuah fenomena dimana terkadang siswa tidak begitu memperdulikan tatanan dalam menjawab ataupun penggunaan simbol yang mereka gunakan dalam menyelesaikan masalah matematika. Hal ini mengindikasikan bahwa kemampuan komunikasi matematis siswa masih belum mencapai hasil yang maksimal. Salah satu yang dapat mempengaruhi kemampuan komunikasi matematis siswa adalah gaya belajar. Penelitian ini bertujuan untuk mendeskripsikan kemampuan komunikasi matematis siswa dengan gaya belajar visual, audiotori, dan kinestetik dalam menyelesaikan masalah matematika materi statistika kelas IX di SMP Negeri 1 Jember. Penelitian ini merupakan penelitian deskriptif. Subyek dalam penelitian ini adalah enam orang siswa yang dipilih berdasarkan gaya belajar, terdiri dari dua siswa gaya belajar visual, dua siswa gaya belajar audiotori, dan dua siswa gaya belajar kinestetik. Pengumpulan data menggunakan angket atau kuisioner, tes kemampuan komunikasi, observasi, wawancara, dan dokumentasi. Analisis data menggunakan model Miles dan Huberman melalui empat tahapan yaitu, pengumpulan data, kondensasi data, penyajian data, dan kesimpulan. Keabsahan data menggunakan triangulasi teknik. Hasilnya menunjukkan bahwa siswa dengan gaya belajar visual mampu memenuhi tiga dari empat indikator kemampuan komunikasi matematis. Siswa dengan gaya belajar audiotori mampu memenuhi tiga dari empat indikator kemampuan komunikasi matematis. Siswa dengan gaya belajar kinestetik mampu memenuhi semua dari empat indikator kemampuan komunikasi matematis.
\end{abstract}

Kata kunci: gaya belajar, kemampuan komunikasi matematis, menyelesaikan masalah

\begin{abstract}
The background of this research starts from a phenomenon where students do not care about the order in answering or using the symbols in solving mathematical problems. This indicates that students' mathematical communication ability is still not achieving the maximum results. One aspect that can affect students' mathematical communication ability is learning styles. This research aims to describe the mathematical communication ability of the students namely visual, auditory, and kinesthetic learning styles in solving mathematical problems at statistical material of IX grade at SMP Negeri 1 Jember. This research is descriptive. The subjects in this research were six students who were selected based on their learning styles. It consists of two students with visual learning styles, two students with auditory learning styles, and two students with kinesthetic learning styles. The data collection used questionnaires, communication ability tests, observations, interviews, and document review. The data analysis used the Miles and Huberman model through four stages namely, data collection, data condensation, data presentation, and conclusions. The validity of the data used triangulation techniques. The results showed that the students with visual learning styles can fulfill three out of four indicators of mathematical communication ability. The students with auditory learning styles can fulfill three out of four indicators of mathematical communication ability. The students with kinesthetic learning styles can fulfill all out of four indicators of mathematical communication ability.
\end{abstract}

Keywords: learning style, mathematical communication, problem solving, 


\section{PENDAHULUAN}

Matematika adalah bahasa simbol dimana setiap orang yang mempelajari matematika dituntut untuk memiliki kemampuan untuk berkomunikasi dengan menggunakan bahasa simbol tersebut. Matematika sebagai bahasa simbol mempunyai makna bahwa matematika bersifat universal dan dapat dipahami oleh setiap orang. Terdapat lima kemampuan dasar yang merupakan standar proses dalam matematika, yaitu kemampuan pemecahan masalah, kemampuan penalaran dan bukti, kemampuan komunikasi, kemampuan koneksi, dan kemampuan representasi (Vebri, 2018).

Tujuan pembelajaran matematika sebagaimana tercantum dalam (Permendiknas Nomor 22 tahun 2006 tentang Standar Isi) disebutkan salah satunya adalah supaya siswa mampu mengkomunikasikan gagasan dengan simbol, tabel, diagram, atau media lain untuk memperjelas keadaan atau masalah (Hamzah, 2014). Tujuan permendiknas ini sejalan dengan tujuan umum pembelajaran matematika yang dirumuskan National Caucil of Teacher of Mathematics (NCTM), salah satunya adalah kemampuan komunikasi matematis (NCTM, 2000).

Komunikasi matematis merupakan kemampuan mengorganisasi dan mengkonsolidasi pikiran matematika melalui komunikasi secara lisan maupun tertulis. Mengkomunikasikan gagasan matematika secara logis dan jelas kepada orang lain, menganalisis dan mengevaluasi pikiran matematika dan strategi yang digunakan oleh orang lain, serta menggunakan bahasa matematika untuk menyatakan ide-ide atau gagasan matematika secara tepat (NCTM, 2000). Pemahaman siswa dalam belajar matematika akan lebih baik ketika siswa mampu mengkomunikasikan ide-ide, gagasan, konsep dari materi yang telah dipelajari pada orang lain. Selain itu, siswa dapat dilatih berkomunikasi menyelesaikan masalah matematika.

Masalah adalah sesuatu yang harus dipecahkan. Di dalam matematika, suatu pernyataan atau soal akan merupakan suatu masalah apabila tidak terdapat aturan atau hukum tertentu yang segera dapat digunakan untuk menjawab atau menyelesaikannya. Situasi yang menjadi masalah bagi seseorang belum tentu menjadi masalah bagi orang lain (Wahyudi dan Aggraheni, 2017). Sejalan dalam 


\section{Profil Kemampuan Komunikasi Matematis Siswa Kelas IX dalam Menyelesaikan Masalah Matematika Materi Statistika Berdasarkan Gaya Belajar}

hal tersebut, Farihah (2018) mengungkapkan bahwa sebagian besar ahli pendidikan matematika menyatakan bahwa masalah adalah pernyataan yang harus dijawab atau direspon. Namun mereka juga menyatakan tidak semua pertanyaaan otomatis akan jadi masalah. Widodo (2013) menyatakan bahwa suatu soal matematika dapat menjadi masalah matematika jika siswa tidak mempunyai gambaran untuk menyelesaikan permasalahan, tetapi siswa berkeinginan untuk menyelesaikan masalah matematika. Menurut Polya (2004) terdapat empat langkah menyelesaikan masalah yaitu, memahami masalah, merencanakan penyelesaian, menyelesaikan masalah sesuai rencana, dan melakukan pengecekan kembali. Pada penyelesaian masalah matematika ini tentunya diperlukan kemampuan matematis. Salah satu kemampuan yang termasuk dalam kemampuan matematis adalah kemampuan komunikasi matematika.

Kemampuan komunikasi matematis juga dapat dipengaruhi oleh faktorfaktor dari dalam siswa (intern)maupun dari luar siswa (extern). Salah satu faktor yang menunjang kemampuan komunikasi matematis siswa yaitu gaya belajar. Menurut Gufran (dalam Danaryanti, 2015) gaya belajar merupakan sebuah pendekatan yang menjelaskan mengenai bagaimana individu belajar atau cara yang ditempuh oleh masing-masing orang untuk berkonsentrasi pada proses, dan menguasai informasi yang sulit serta baru melalui persepsi yang berbeda. Sejalan dalam hal tersebut, Gunawan (dalam Nurhidayah, 2015) mengungkapkan gaya belajar adalah cara yang lebih kita sukai dalam melakukan kegiatan berfikir, memproses dan mengerti suatu informasi.Menurut Deporter \& Hernachi (dalam Sari, 2017) gaya belajar dapat digolongkan menjadi tiga macam gaya diantaranya (1) Gaya belajar visual yaitu belajar melalui melihat sesuatu, artinya bukti-bukti konkrit harus diiperhatikan terlebih dahulu agar siswa paham. Ciri-ciri siswa yang memiliki gaya belajar visual adalah kebutuhan yang tinggi untuk melihat dan menangkap informasi secara visual sebelum ia memahaminya. (2) Gaya auditori yaitu belajar melalui mendengarkan sesuatu. Siswa yang mempunyai gaya belajar audiotori dapat belajar lebih cepat dengan menggunakan diskusi verbal dan mendengarkan apa yang guru katakan dan (3) Gaya belajar kinestetik yaitu belajar melalui aktivitas fisik dan keterlibatan langsung. Siswa seperti ini mempunyai 
keunikan dalam belajar selalu bergerak, aktivitas panca indera dan menyentuh. Siswa seperti ini sulit untuk diam berjam-jam karena keinginan mereka untuk beraktivitas dan eksplorasi sangatlah kuat. Ketiga gaya belajar ini ada individu yang cenderung pada salah satu gaya, dan ada juga cenderung dengan semua gaya belajar.

Penelitian ini menggunakan indikator-indikator yang digunakan untuk mengukur kemampuan komunikasi matematis siswa secara tertulis ataupun lisan dalam penelitian ini diadopsi berdasarkan kebutuhan penelitian dengan mengacu pada indikator NCTM pada Tabel 1.

Tabel 1. Indikator Kemampuan Komunikasi Matematis (Vebri, 2018)

\begin{tabular}{|c|c|c|c|}
\hline \multirow{2}{*}{ No. } & \multirow{2}{*}{ Indikator NCTM } & \multicolumn{2}{|c|}{ Penjabaran Indikator } \\
\hline & & Komunikasi Tulis & Komunikasi Lisan \\
\hline 1 & $\begin{array}{l}\text { Kemampuan } \\
\text { mengekspresikan ide- } \\
\text { ide matematika melalui } \\
\text { lisan, tulisan, dan } \\
\text { mendemonstrasikannya } \\
\text { serta } \\
\text { menggambarkannya } \\
\text { secara visual. }\end{array}$ & $\begin{array}{l}\text { Mengekspresikan } \\
\text { gagasan matematika } \\
\text { dengan menuliskan } \\
\text { informasi yang ada } \\
\text { pada masalah dengan } \\
\text { menuliskan apa yang } \\
\text { diketahui dan ditanya }\end{array}$ & $\begin{array}{l}\text { Mengekspresikan } \\
\text { gagasan matematika } \\
\text { dengan menyebutkan } \\
\text { informasi yang ada } \\
\text { pada masalah dengan } \\
\text { menyebutkan apa } \\
\text { yang diketahui dan } \\
\text { ditanya }\end{array}$ \\
\hline 2 & $\begin{array}{l}\text { Kemampuan } \\
\text { memahami, } \\
\text { menginterpretasikan, } \\
\text { dan mengevaluasi ide- } \\
\text { ide matematika baik } \\
\text { secara lisan maupun } \\
\text { bentuk visual lainnya }\end{array}$ & $\begin{array}{l}\text { Memahami dan } \\
\text { menginterpretasikan } \\
\text { gagasan dengan } \\
\text { menuliskan strategi } \\
\text { dan langkah } \\
\text { penyelesaian secara } \\
\text { runtut dan sistematis } \\
\text { Mengevaluasi gagasan } \\
\text { dengan menuliskan } \\
\text { kesimpulan di akhir } \\
\text { penyelesaian masalah }\end{array}$ & $\begin{array}{l}\text { Menjelaskan strategi } \\
\text { dan langkah-langkah } \\
\text { penyelesaian dari } \\
\text { masalah dengan } \\
\text { runtut dan sistematis }\end{array}$ \\
\hline 3 & $\begin{array}{l}\text { Kemampuan } \\
\text { menggunakan istilah, } \\
\text { notasi matematika dan } \\
\text { struktur-strukturnya } \\
\text { untuk menyajikan ide, } \\
\text { menggambarkan } \\
\text { hubungan dan model } \\
\text { situasi }\end{array}$ & $\begin{array}{l}\text { Menggunakan simbol- } \\
\text { simbol matematika } \\
\text { dalam menuliskan } \\
\text { penyelesaian masalah }\end{array}$ & $\begin{array}{l}\text { Mengungkapkan } \\
\text { penggunaan simbol- } \\
\text { simbol matematika } \\
\text { pada penyelesaian } \\
\text { masalah }\end{array}$ \\
\hline
\end{tabular}




\section{Profil Kemampuan Komunikasi Matematis Siswa Kelas IX dalam Menyelesaikan Masalah Matematika Materi Statistika Berdasarkan Gaya Belajar}

Beberapa data penelitian menunjukkan bahwa siswa yang belajar dengan gayanya akan memiliki kemampuan komunikasi matematika yang lebih baik dan berbeda-beda (Sari, 2017). Hal tersebut diperkuat oleh penelitian yang dilakukan oleh Rizki Wulandari (2018) menunjukkan bahwa kemampuan komunikasi matematis siswa dengan gaya belajar visual memenuhi tiga indikator kemampuan komunikasi matematis, gaya belajar auditori memenuhi dua indikator kemampuan komunikasi matematis, dan gaya belajar kinestetik memenuhi dua indikator kemampuan komunikasi matematis. Hasil penelitian yang dilakukan oleh Anis Safitri (2016) menunjukkan bahwa siswa dengan gaya belajar visual dapat memenuhi semua indikator kemampuan komunikasi matematis, gaya belajar auditori dapat memenuhi semua indikator kemampuan komunikasi matematis, dan siswa dengan gaya kinestetik hanya mampu memenuhi tiga dari empat indikator kemampuan komunikasi matematis. Indikator

Dengan adanya perbedaan siswa dalam mengolah informasi, menyebabkan berbeda pula kemampuan komunikasi matematis siswa. Penelitian ini terfokus pada siswa kelas IX SMPN 1 Jember yang telah memperoleh materi statistika sebelumnya, sehingga lebih mempermudah penelitian yang bertujuan untuk mendeskripsikan kemampuan komunikasi matematis siswa dengan gaya belajar visual, audiotori, dan kinestetik.

\section{METODE PENELITIAN}

Penelitian ini menggunakan pendekatan kualitatif dan jenis penelitian ini adalah penelitian deskriptif. Subyek penelitian ini adalah siswa kelas IX SMPN 1 Jember Semester Ganjil Tahun Pelajaran 2019/2020 sebanyak enam orang siswa dengan dominasi gaya belajar yang berbeda, yakni dua gaya belajar visual, dua gaya belajar audiotori, dan dua gaya belajar kinestetik. Siswa yang dijadikan subyek adalah mereka yang mampu berkomunikasi dengan baik dan memiliki satu dominasi gaya belajar. Langkah awal adalah menentukan subyek penelitian. Peneliti melakukan identifikasi gaya belajar siswa di kelas IX SMPN 1 Jember. Dari seluruh siswa kelas IX yang telah diberikan tes gaya belajar, dipilih enam 
siswa dengan skor dominasi gaya belajar tertinggi. Berikut merupakan daftar subyek penelitian,

Tabel 2. Daftar Subyek Penelitian Berdasarkan Gaya Belajar

\begin{tabular}{cccccc}
\hline No & Kode & Skor Visual & Skor Auditori & $\begin{array}{c}\text { Skor } \\
\text { Kinestetik }\end{array}$ & Gaya Belajar \\
\hline 1 & JS & 39 & 32 & 30 & Visual \\
2 & MA & 41 & 31 & 33 & Visual \\
3 & VP & 31 & 39 & 32 & Auditori \\
4 & EN & 29 & 36 & 27 & Auditori \\
5 & AR & 28 & 30 & 38 & Kinestetik \\
6 & RF & 24 & 28 & 36 & Kinestetik \\
\hline
\end{tabular}

Metode pengumpulan data dilakukan dengan menggunakan angket atau kuisioner, tes kemampuan komunikasi, observasi, wawancara, dan dokumentasi. Analisis data yang digunakan dalam penelitian ini terdiri dari dua macam. Pertama, analisis gaya belajar siswa ditentukan dengan cara menjumlahkan skor gaya belajar. Kedua, analisis kemampuan komunikasi matematis siswa dalam menyelesaikan masalah matematika menggunakan model Miles dan Huberman (2014). Aktivitas dalam analisis data ini adalah pengumpulan data, kondensasi data, penyajian data, dan kesimpulan. Keabsahan data menggunakan triangulasi teknik yaitu menguji kreabilitas data dengan cara mengecek data kepada sumber yang sama.

\section{HASIL PENELITIAN DAN PEMBAHASAN}

Tes kemampuan komunikasi matematis dengan masalah statistika diberikan kepada subyek penelitian untuk diselesaikan. Hasil penelitian menunjukkan bahwa siswa yang memiliki gaya belajar visual dan audiotori mampu memenuhi tiga dari empat indikator kemampuan komunikasi matematis. Sedangkan siswa dengan gaya belajar kinestetik mampu memenuhi empat dari semua indikator.

Berikut ini adalah deskripsi kemampuan bernalar siswa dalam menyelesaikan masalah materi statistika, 
Soal 1: Berikut ini data nilai 20 siswa kelas VIII pada ulangan tengah semester matematika,

Tabel 3. Nilai 20 Siswa Kelas VII

\begin{tabular}{llllllllllll}
\hline No & $\mathbf{1}$ & $\mathbf{2}$ & $\mathbf{3}$ & $\mathbf{4}$ & $\mathbf{5}$ & $\mathbf{6}$ & $\mathbf{7}$ & $\mathbf{8}$ & $\mathbf{9}$ & $\mathbf{1 0}$ \\
\hline Nama & Indah & Sari & Ria & Maya & Rino & ica & Tri & Syifa & Novi & Ita \\
Nilai & 5 & 9 & 6 & 9 & 9 & 7 & 6 & 5 & 6 & 8 \\
\hline No & $\mathbf{1 1}$ & $\mathbf{1 2}$ & $\mathbf{1 3}$ & $\mathbf{1 4}$ & $\mathbf{1 5}$ & $\mathbf{1 6}$ & $\mathbf{1 7}$ & $\mathbf{1 8}$ & $\mathbf{1 9}$ & $\mathbf{2 0}$ \\
\hline Nama & Reno & Farah & Titik & Tio & Pipin & Nita & Sisca & Lely & Putri & Pipit \\
Nilai & 5 & 9 & 6 & 9 & 9 & 7 & 6 & 5 & 6 & 8 \\
\hline
\end{tabular}

Buatlah tabel distribusi frekuensi, agar mudah diketahui berapakah banyaknya siswa yang memiliki nilai tertentu. Jika siswa yang lulus adalah yang memiliki nilai di atas rata-rata, maka berapa banyak siswa yang lulus?

Subyek visual yaitu subyek JS dan MA dalam menyelesaikan masalah pada tes tulis kedua subyek tidak menuliskan apa yang diketahui dan ditanyakan. Namun hasil wawancara menunjukkan bahwasanya subyek mampumenyebutkan informasi yang ada pada soal. Hal ini menunjukkan bahwa subyek mampu memenuhi indikator pertama lisan dengan benar. Seperti yang telah diutarakan oleh subyek yaitu, "Mencari, nilai data anak-anak sama jumlah anak-anak siswa kelas VIII 20 siswa, ditanya dicari nilai banyak siswa yang lulus memiliki nilai diatas rata-rata sama membuat tabel frekuensi”.

Pada tahap memahami dan menginterpretasikan gagasan dengan menuliskan strategi dan langkah penyelesaian secara runtut dan sistematis, Subyek JS dan MA. Langkah yang pertama subyek MA yaitu menuliskan penjumlahan semua nilai siswa kemudian dibagi 20 dan hasilnya 7,1. Kedua, subyek menggambar tabel distribusi namun memiliki kekeliruan dalam hasilnya. Sedangkan JS membuat tabel distribusi dan menuliskan rata-rata $=7,6$ dari hasil $\frac{152}{120}$. Kedua subyek gaya belajar visual mampu memenuhi indikator kedua komunikasi tulis walaupun tidak menuliskan strategi dan langkah penyelesaian secara runtut dan sistematis. Berikut hasil wawancara dengan subyek, 
JS : Yang pertama saya lakukan mengurutkan nilai dari yang terkecil ke yang terbesar setelah itu kalau sudah ketemu siswa ada berapa dikalikan sama nilainya setelah itu di jumlah habis itu banyak siswa dijumlah sama semua hasil nilainya terus dibagi. Terus ketemu rata-ratanya 7,6 bu. siswa yang mendapatkan nilai diatas rata-rata 7,6 adalah 11 anak. yaitu 8 ada 4, 9 ada 6 dan 10 ada 1.

Pada tahap ini, kedua subyek Gaya Belajar Visual mampu memenuhi indikator komunikasi lisan kedua secara runtut dan sistematis. Pada tahap mengevaluasi gagasan, kedua subyek visual sama-sama mampu menuliskan kesimpulan diakhir. Sehingga kedua subyek mampu memenuhi indikator ketiga komunikasi tulis. Sama halnya dengan pemaparan subyek MA yaitu, “ jadi siswa yang lulus ada 15 orang bu". Hasil wawancara menunjukkan bahwasanya kedua subyek memenuhi indikator ketiga komunikasi lisan.

Pada tahap terahir menggunakan simbol-simbol matematika, subyek MA dan JS tidak mampu memenuhi indikator keempat komunikasi tulis dan lisan karena lupa. Sebagaimana dengan wawancara yang dilakukan kepada subyek, "Tidak menggunakan simbol bu, lupa simbolnya apa". Hasil tes atau solusi subyek gaya belajar visual dalam menyelesaikan soal no 1 diberikan pada Gambar 1.

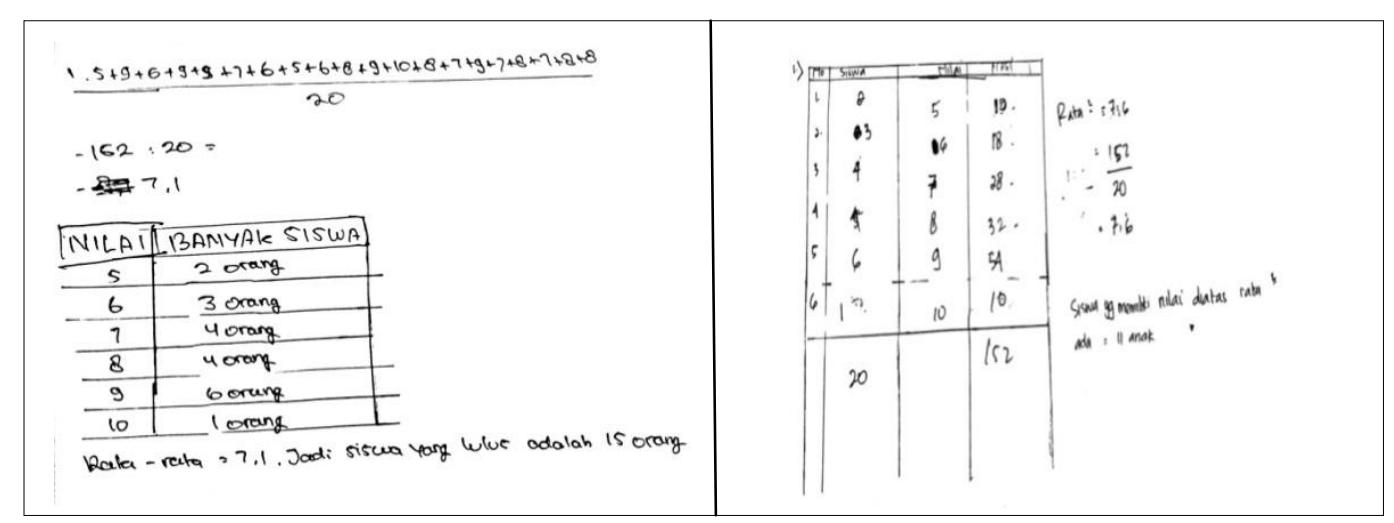

Gambar 1. Solusi Subyek MA (Kiri) dan JS (Kanan) Menyelesaikan Soal 1

Kedua subyek Gaya Belajar Audiotori yaitu subyek EN dan VP menyelesaikan masalah tanpa menuliskan informasi yang diketahui yang terdapat pada soal. Hal ini menunjukkan bahwa subyek kurang mampu dalam memberikan 
informasi dalam soal secara tertulis. Namun pada saat wawancara kedua subyek visual subyek mampu mengkomunikasikan secara lisan indikator pertama dengan benar dan lengkap. Berikut penjelasan subyek VP yaitu, "Jumlah siswa itu ada 20 bu, terus yang ditanyakan banyak siswa yang lulus yang memiliki nilai diatas ratarata”. Senada dengan hal tersebut, subyek EN juga menyatakan bahwa, “iya bu, yang diketahui jumlah nilai sama banyak siswa bu, yang ditanyakan rata-rata sama banyak siswa yang lulus diatas rata-rata”.

Pada tahap memahami dan menginterpretasikan gagasan, Subyek EN menyelesaikan masalah tidak menuliskan rumus dan langkah-langkah secara runtut dan sistematis. Hal ini menunjukkan bahwasanya subyek kurang mampu melaksanankan komunikasi tertulis pada indikator kedua dengan benar. Namun hasil wawancara menunjukkan bahwasanya kedua subyek gaya belajar audiotori mampu mengkomunikasikan secara lisan indikator kedua dengan benar dan lengkap. Berikut hasil wawancara pada subyek EK, "152 itu dari jumlah semua nilai dibagi 20 jumlah banyaknya siswa. Jadi ketemu rata-ratanya, terus untuk siswa yang lulus ada 11 orang bu. Kan rata-ratanya 7,6 Jadi dicari nilai yang diatas 7,6 disini dari nilai 8,9 sampai 10. Dijumlah ada berapa orang bu. Ketemu 11 orang".

Pada tahap mengevaluasi, kedua subyek mampu menuliskan kesimpulan diakhir penyelesaian dengan benar yaitu siswa yang lulus adalalah 11 orang. Hasil wawancara menunjukkan bahwasanya subyek mampu memenuhi indiktor komunikasi lisan yaitu, "jadi, siswa yang lulus ada 11 orang”. Sedangkan pada tahap terahir menggunakan simbol-simbol matematika, kedua subyek belum mampu memenuhi indikator keempat komunikasi tulis dan lisan.Seperti hasil wawancara yang dilakukan pada kedua subyek, "Tidak ada, saya tidak tahu. Hasil tes atau solusi subyek gaya belajar audiotori dalam menyelesaikan soal no 1 diberikan pada Gambar 2. 


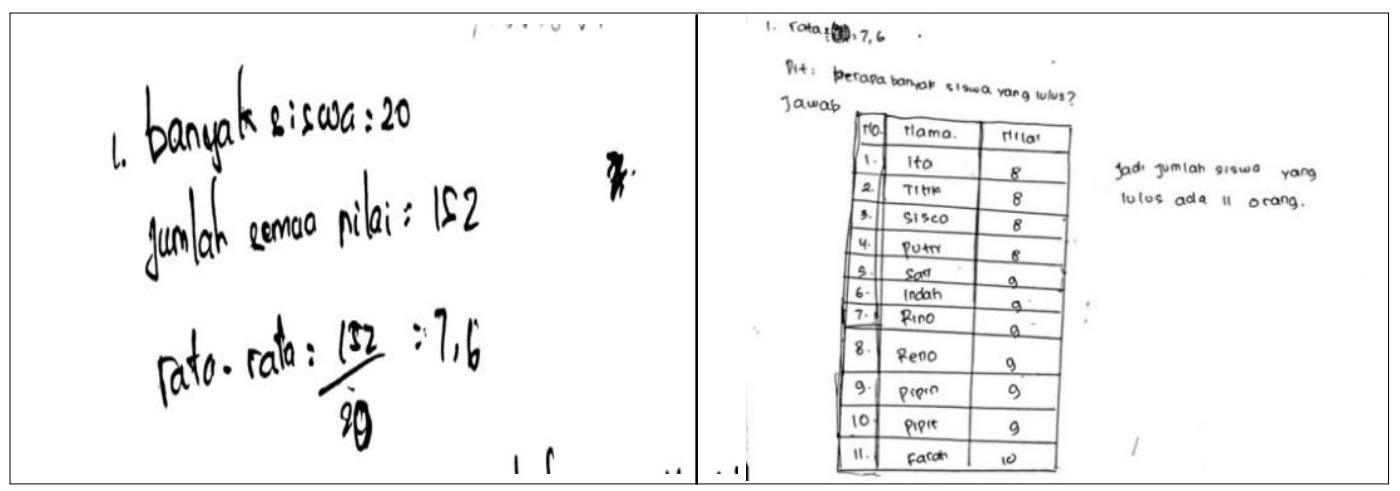

Gambar 2. Solusi Subyek EK (Kiri) dan VP (Kanan) Menyelesaikan Soal 1

Subyek Gaya Belajar Kinestetik yaitu subjek AR menuliskan informasi yang diketahui dan ditanyakan pada dengan menggunakan tabel distribusi frekuensi. Sementara subyek RF tidak menuliskan informasi yang terdapat pada soal. Hal tersebut menunjukkan bahwa subyek RF belum mampu memenuhi indikator pertama komunikasi tulis. Namun kedua subyek mampu memenuhi komunikasi lisan hal tersebut diperoleh dari hasil wawancara yang dilakukan kepada subyek RF yaitu, “yang diketahui yaitu data nilai 20 siswa kelas VIII pada ulangan tengah semester matematika dan yang ditanyakan itu berapa banyak siswa yang lulus diatas rata-rata".

Pada tahap selanjutnya, subyek AR menuliskan strategi dan langkah penyelesaian dengan runtut dan sistematissedangkan subyek RF menuliskan 20 nilai semua siswa kemudian mengalikan dengan berapa kali nilai itu muncul dan membaginya dengan 20 dan menghasilkan nilai 7,6. Pada tahap ini, kedua subyek gaya belajar kinestetik mampu memenuhi indikator kedua komunikasi tulis. Berikut wawancara kepada subyek AR, "Saya membuat tabel distribusi frekuensi dulu, kemudian mencari rata-rata dan nilai diatas rata-rata berati harus mencari frekuensinya dulu dan saya tulis di tabel. Kemudian frekuensi dijumlah nilai juga dijumlah kemudian saya masukkan kedalam rumus. Terus ketemu 7,6 setelah itu mencari nilai diatas rata-rata yaitu ada 11 orang".

Hasil wawancara menunjukkan bahwasanya kedua subyek mampu memenuhi indikator kedua komunikasi lisan dengan benar dan lengkap. Selanjutnya pada tahap ketiga, kedua subyek mampu memenuhi indikator ketiga 
tulis dan lisan.Berikut wawancara kepada subyek, subyek RF, "jadi, rata-rata dari nilai siswa kelas VIII adalah 7,6. Berati nilai yang diatas rata-rata ada 11 orang”.

Pada tahap menggunakan simbol-simbol matematika subyek AR menuliskan rumus menggunakan simbol rata-rata dengan benar yaitu $\bar{x}$. Sedangkan subyek RF tidak. Namun, hasil wawancara menunjukkan kedua subyek mampu memenuhi indikator ketiga komunikasi lisan. Berikut wawancara yang dilakukan kepada subyek RF yaitu, "tidak saya tuliskan, tidak terbiasa. Tau, $x$ yang kemudian diatasnya ada garisnya $(\bar{x})$ lupa namanya". Hasil tes atau solusi subyek gaya belajar audiotori dalam menyelesaikan soal no 1 diberikan pada Gambar 3.

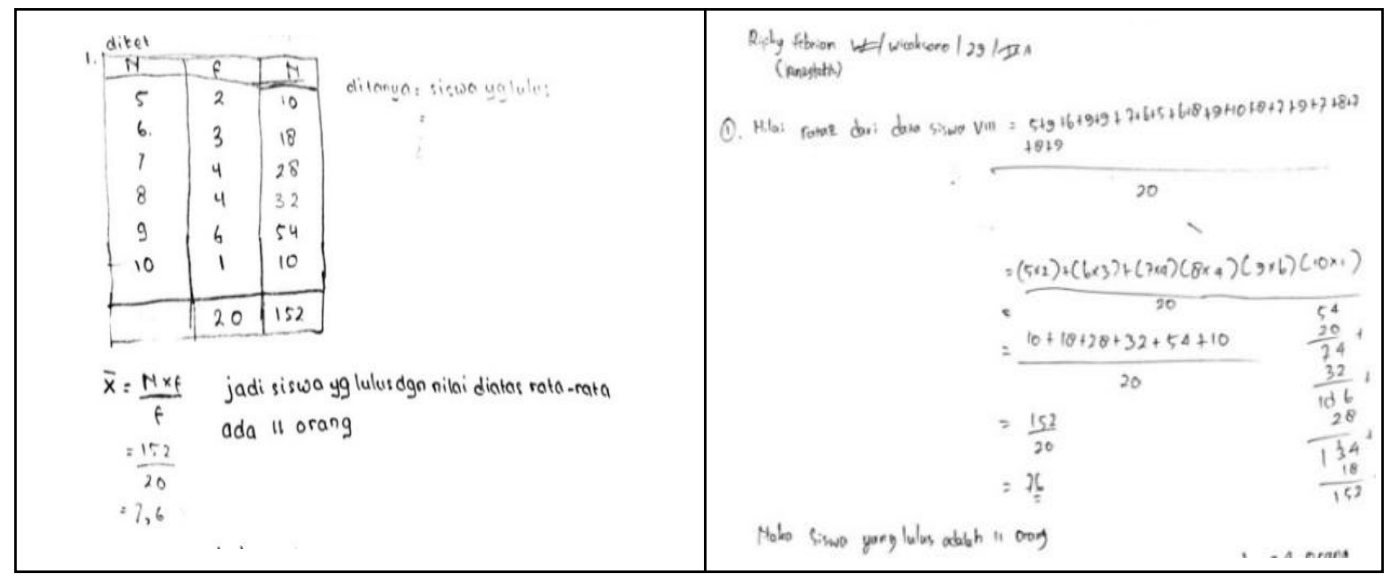

Gambar 3. Solusi Subyek AR (Kiri) dan RF (Kanan) Menyelesaikan Soal 1

Soal 2 : Data nilai ulangan siswa kelas VII sebagai berikut:

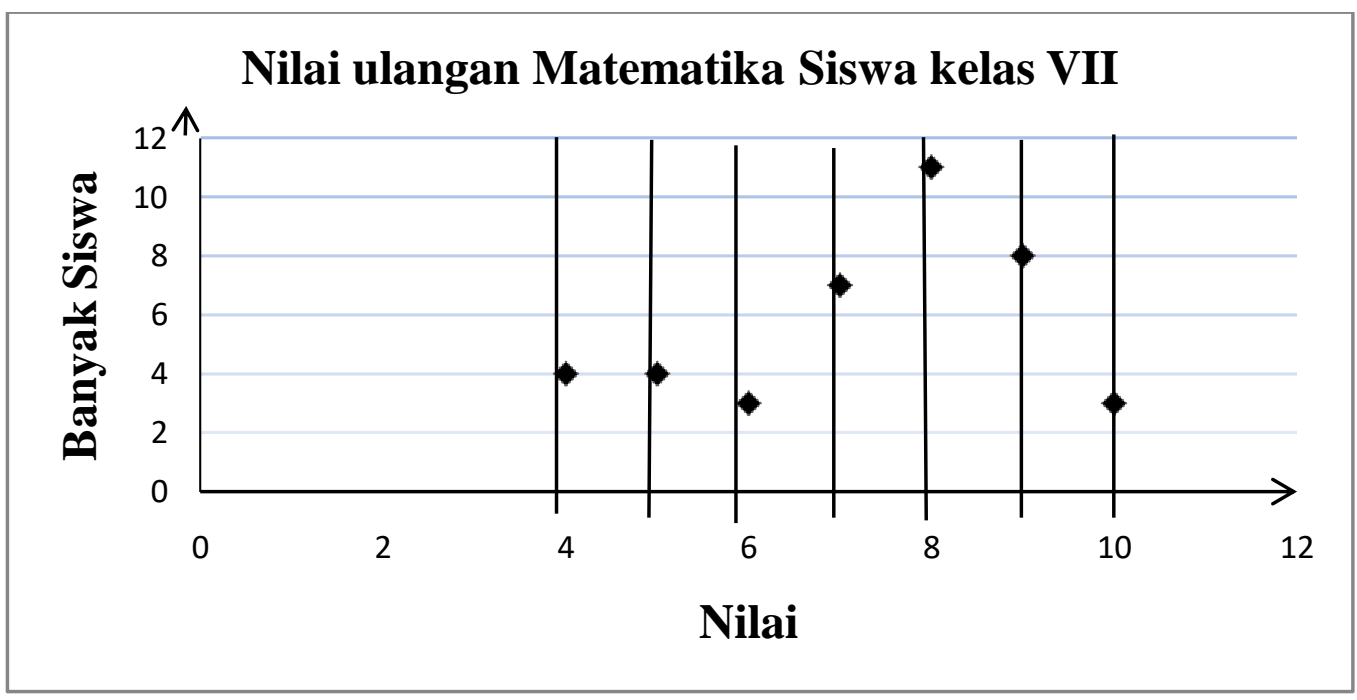

Gambar 4. Data Nilai Ulangan Siswa Kelas VII 


\section{Tentukan median dan modus dari data tersebut.}

Subyek Visual yaitu subyek MA dan JS menyelesaikan masalah tanpa menuliskan informasi yang terdapat pada soal. Hal ini menunjukkan kedua subyek belum mampu melaksanakan indikator komunikasi tulis pertama. Namun hasil wawancara menunjukkan kedua subyek mampu memenuhi indikator pertama komunikasi lisan seperti pemaparan yang telah diungkapkan oleh subyek MA yaitu, "Yang diketahui data tabel 15 orang, yang ditanyakan mencari median dan membuat diagram".

Pada tahap selanjutnya, Subyek MA dan JS menuliskan kesalahan strategi penyelesaian yaitu dengan mengurutkan dan menuliskan data dari yang terkecil ke yang terbesar dan menentukan nilai yang tengah. Tetapi, untuk modus kedua subyek menjawab dengan benar dengan strategi yang benar. Kedua subyek menunjukkan bahwa kurang mampu memenuhi indikator kedua komunikasi tulis dan lisan. Hal tersebut juga diungkapkan oleh subyek MA dalam wawancara, "Median tujuh bu dari data yang sudah diurutkan bu, modusnya delapan karena nilai delapan paling banyak bu".

Selanjutnya Gaya Belajar Visual sama-sama tidak menuliskan kesimpulan di akhir penyelesaian. Namun, kedua subyek mampu mengevaluasi gagasan secara lisan sebagaimana pada saat diwawancara subyek mengatakan, "Jadi, modus 7 dan mediannya 8 ". Sedangkan pada tahap menggunakan simbol-simbol matematika kedua subyek belum mampu menulis dan menyebutkan. Sebagaimana wawancara kepada subyek yaitu, "Saya tidak tahu". Hal tersebut menunjukkan kedua subyek belum mampu memenuhi indikator lisan keempat. Hasil tes atau solusi subyek gaya belajar audiotori dalam menyelesai kan soal no 2 diberikan pada Gambar 5.

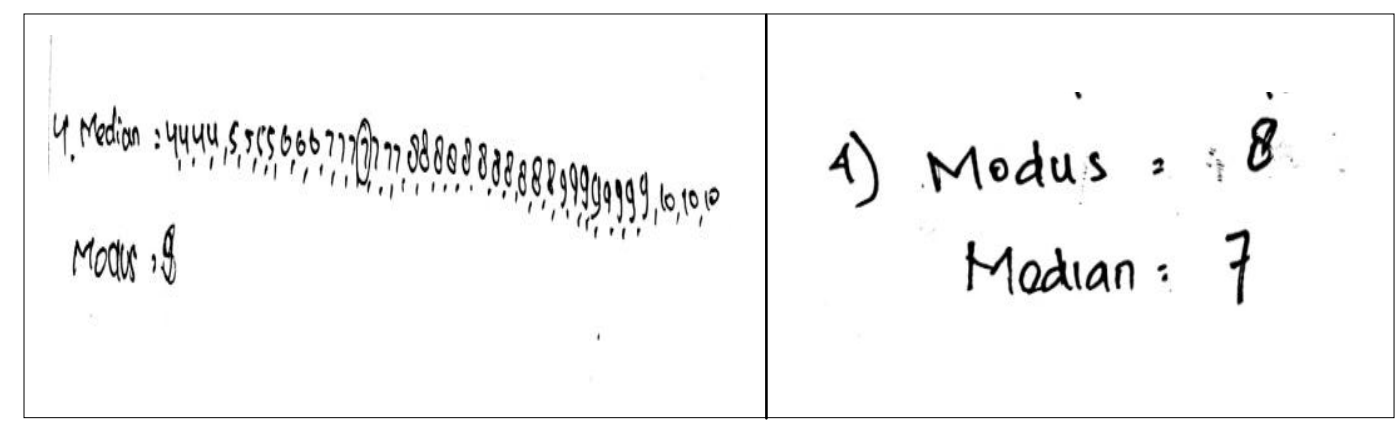

Gambar 5. Solusi Subyek MA (Kiri) dan JS (kanan) Menyelesaikan Soal 2 


\section{Profil Kemampuan Komunikasi Matematis Siswa Kelas IX dalam Menyelesaikan Masalah Matematika Materi Statistika Berdasarkan Gaya Belajar}

Subyek gaya belajar Audiotori yaitu subjek VP menuliskan informasi yang diketahui pada soal dengan menggunakan tabel distribusi frekuensi dan menulis yang ditanya. Sementara subyek EN hanya menuliskan apa yang ditanyakan akan tetapi siswa kurang melengkapi pada bahwa yang ditanyakan adalah median dan modus. Meskipun subyek EN tidak mampu menuliskan informasi pada soal dengan lengkap, kedua subyek gaya belajar audiotori mampu memenuhi indikator pertama komunikasi lisan. Berikut hasil wawancara yang dilakukan kepada subyek yaitu, "Nilai sama banyaknya siswa, ditanyakan median sama modus".

Pada tahap selanjutnya subyek EN hanya menuliskan rumus median namun tidak menuliskan penyelesaian dengan lengkap. Sedangkan subyek VP menuliskan strategi penyelesaian dengan menjumlahkan dua nilai tengah kemudian dibagi dua. Subyek VP memberikan tanda di tabel distribusi pada angka 11 yaitu jumlah terbanyak siswa untuk hasil modusnya yaitu 8 . Hal ini menunjukkan bahwasanya subyek EN tidak mampu melaksanakan komunikasi tulis. Namun ketika wawancara kedua subyek mampu memenuhi indikator kemampuan komunikasi lisan kedua. Berikut hasil wawancara subyek yaitu, "Mencari modus nilai yang paling sering muncul kemudian mediannya dengan

rumus $\frac{(\text { jumlah semua data })}{2}+1=\frac{(40)}{2}+1=20,5=8$ mediannya 8 . Modusnya 8 juga modus itu yang paling sering muncul".

Pada tahap mengevaluasi, subyek VP mampu memenuhi indikator tulis ketiga sedangkan subyek EN tidak. Kesimpulan yang diperoleh subyek VP dapat dibuktikan dengan perhitungan median yaitu $\frac{\text { Jumlah data }}{2}$. menuliskan kesimpulannya diakhir penyelesaian. Namun meskipun EN tidak menuliskan kesimpulannya, kedua subyek audiotori mampu memenuhi indikator ke tiga komunikasi lisan mengevaluasi gagasan matematika. Sebagaimana hasil wawancara dengan subyek, yaitu "Jadi, median 8 dan Modusnya 8".

Pada tahap selanjutnya yaitu menggunakan simbol-simbol matematika subyek EN dan VP belum mampu memenuhi indikator tulis dan lisan. Sebagaimana wawancara kepada subyek yaitu, "Saya tidak tahu". Hasil tes atau solusi subyek gaya belajar audiotori dalam menyelesaikan soal no 2 diberikan pada Gambar 6. 


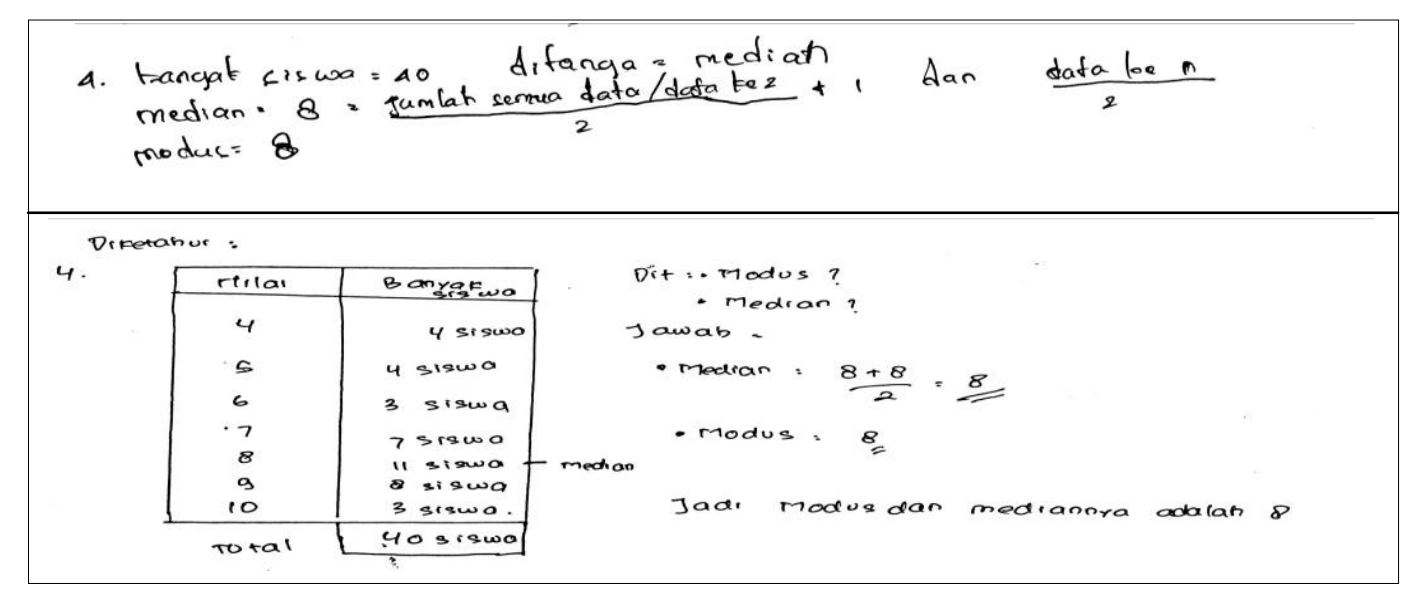

Gambar 6. Solusi Subyek EN (Atas) dan VP (Bawah) Menyelesaikan Soal 2

Subyek Gaya Belajar Kinestetik RF menyelesaikan masalah dengan menuliskan nilai dan banyaknya siswa. Sedangkan subyek AR tidak. Namun meskipun AR tidak menuliskan informasi pada soal subyek AR mampu memenuhi indikator pertama komunikasi lisan sebagaimana yang telah dipaparkan oleh subyek AR, "Nilai siswa dan banyak siswa, ditanyakan modus dan median. Pada tahap selanjutnya, subyek RF tidak menuliskan strategi dalam menyelesaikan masalah sedangkan AR menyelesaikan masalah menuliskan strategi penyelesaian yang digunakan dengan lengkap. Namun ketika di wawancara. Subyek RF menjawab dan menjelaskan langkah-langkah dengan runtut namun melakukan kesalahan. Hal tersebut menujukkan subyek kurang mampu memenuhi indikator komunikasi tulis dan lisan. Berikut hasil wawancara subyek RF, “Langkah-langkah mencari median menuliskan data dari yang terkecil sampai terbesar kemudian tinggal mengetahui banyak data dan mencari banyak data dibagi dua. Kemudian cara mencari modusnya adalah mencari nilai yang paling banyak sering muncul yaitu 8 karena yang mempunyai nilai 8 sebanyak 11 orang".

Kedua subyek AN dan RF sama-sama tidak menuliskan kesimpulan di akhir. Hal tersebut menunjukkan kedua subyek belum mampu memenuhi indikator komunikasi tulis yang ketiga. Namun kedua subyek mampu memenuhi indikator komunikasi lisan sebagaimana pada saat diwawancara subyek AN mengatakan, "Jadi, modus yang paling sering muncul adalah 8 dan median data ke 20 adalah 8 juga". 
Sedangkan pada tahap selanjutnya yaitu menggunakan simbol-simbol matematikasubyek ARdan RF belum mampu menuliskan simbol karena subyek RF tidak tahu simbolnya. Sedangkan subyek AR lupa tidak menuliskan. Sebagaimana wawancara kepada subyek yaitu, "Tidak menggunakan simbol, saya tidak tau juga." Hal tersebut menunjukkan kedua subyek belum mampu memenuhi indikator tulis dan lisan keempat. Hasil tes atau solusi subyek gaya belajar audiotori dalam menyelesaikan soal no 2 diberikan pada Gambar 7.

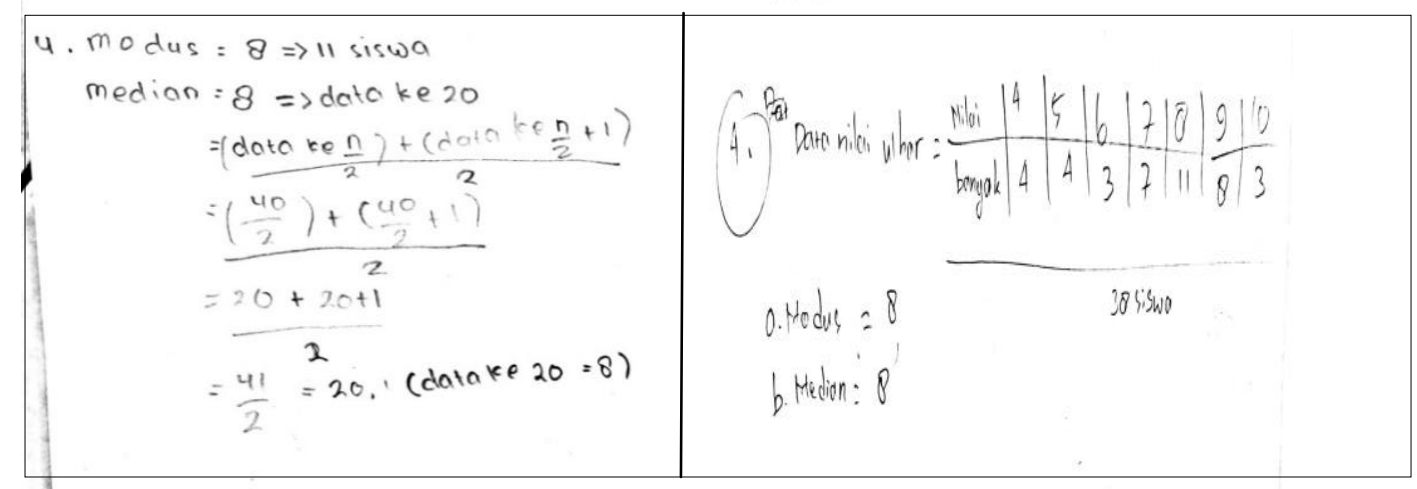

Gambar 7 Solusi Subyek AR (Kiri) dan RF (Kanan) Menyelesaikan Soal 2

Hasil penelitian ini menunjukkan bahwa gaya belajar visual dalam menyelesaikan masalah matematika materi statistika mampu memenuhi tiga dari empat indikator, yaitu mampu sampai pada tahap mengevaluasi gagasan. Gaya belajar visual menjawab setiap pertanyaan yang diberikan dengan singkat dan seperlunya. Hal tersebut didukung oleh sebuah pernyataan menurut Deporter dan Herachi (dalam Nurhidayah, 2015) yang mengungkapkan salah satu ciri siswa dengan gaya belajar visual adalah menjawab pertanyaan dengan jawaban singkat, ya atau tidak. Siswa dengan gaya belajar visual mampu dalam mengekspresikan gagasan matematika dengan mengambarkan tabel dalam menyelesaikan masalah. Hal tersebut didukung oleh Mahmudi (2010) menyatakan bahwa komunikasi matematis secara tertulis dapat berupa panggunaan kata-kata, gambar, tabel dan sebagainya yang menggambarkan proses berfikir siswa.

Siswa dengan gaya belajar visual mampu memahami, menginterpretasikan, dan mengevaluasi ide-ide matematika. Hal ini sesuai dengan penelitian Rizki Wulandari (2018) yang mengungkapkan bahwa siswa dengan 
gaya belajar visual mampu memberikan penjelasan atas jawaban yang telah diberikan.

Hasil penelitian ini sejalan dengan hasil penelitian Rizky wulandari (2018) yang menyatakan bahwa kemampuan komunikasi matematis siswa gaya belajar visual hanya memenuhi tiga dari empat indikator dan berbeda dengan hasil penelitian yang dilakukan oleh Anis Safitri (2016) yang menemukan bahwa siswa dengan gaya belajar visual dapat memenuhi semua indikator kemampuan komunikasi matematis.

Berdasarkan hasil temuan, siswa yang memiliki gaya belajar audiotori dalam menyelesaikan masalah matematika materi statistika mampu memenuhi tiga dari empat indikator yaitu mampu sampai pada tahap mengevaluasi gagasan. Gaya belajar audiotori tidak selalu menuliskan apa yang diketahui dan ditanyakan yang terdapat pada soal. Namun, ketika di wawancara subyek mampu menjawab dan menjelaskan setiap pertanyaan yang diajukan. Hal tersebut sejalan dengan pendapat Deporter dan Heracki (dalam Nurhidayah, 2015) yang menyatakan bahwa gaya belajar audiotori merasa kesulian untuk menulis, namun dapat belajar lebih cepat dengan menggunakan diskusi verbal dan mendengarkan apa yang guru katakan. Siswa dengan gaya belajar audiotori mampu dalam mengekspresikan gagasan matematika dengan menyebutkan informasi yang ada dalam masalah, mampu memahami, menginterpretasikan, dan mengevaluasi ide-ide matematikanya dengan baik, Hal tersebut didukung oleh (NCTM, 2000). Siswa dengan gaya belajar ini tidak dapat menuliskan rumus-rumus dengan benar namun dapat melakukan penyelesaian masalah dengan langkah-langkah yang benar sehingga dapat mengevaluasi.

Hasil penelitian ini berbeda dengan hasil penelitian Rizky wulandari (2018) yang menyatakan bahwa kemampuan komunikasi matematis siswa gaya belajar audiotori memenuhi dua dari empat indikator kemampuan komunikasi matematis, dan hasil penelitian Anis Safitri (2016) yang menunjukkan bahwa siswa dengan gaya belajar audiotori dapat memenuhi semua indikator.

Berdasarkan hasil temuan, siswa yang memiliki gaya belajar kinestetik dalam menyelesaikan masalah matematika materi statistika mampu memenuhi semua dari empat indikator yaitu mampu sampai pada tahap menggunakan 
simbol-simbol matematika dalam menyelesaikan masalah. Siswayang memiliki gaya belajar kinestetik dalam menjawab pertanyaan yang diajukan dengan perlahan menggerakkan pulpen yang sedang berada di tangannya seolah-olah subyek sudah berhasil dalam menjalankan tugasnya. Hal ini didukung oleh sebuah pernyataan Deporter dan Heracki (dalam Nurhidayah, 2015) yang mengungkapkan bahwa salah satu ciri siswa yang memiliki gaya belajar kinestetik adalah banyak menggunakan isyarat tubuh dan berbicara dengan perlahan.

Siswa dengan gaya belajar kinestetik mampu dalam mengekspresikan gagasan matematika dan juga dengan menggunakan tabel dalam menyelesaikan masalah. Hal tersebut didukung oleh NCTM (2000) yang mengungkapkan bahwa salah satu indikator kemampuankomunikasi adalam kemampuan untuk mengekspresikan ide matematika melalui lisan, tulisan, dan mendemostrasikannya serta menggambarkannya secara visual. Mahmudi (2010) juga menyatakan bahwa komunikasi matematis secara tertulis dapat berupa panggunaan kata-kata, gambar, tabel dan sebagainya yang menggambarkan proses berfikir siswa. Siswa dengan gaya belajar ini dapat menuliskan rumus-rumus yang digunakan dengan benar dan telah melakukan penyelesaian masalah dengan langkah-langkah yang sesuai. Hal tersebut didukung oleh NCTM (2000) yang mengungkapkan bahwa siswa harus mampu memahami, menginterpretasikan serta mengevaluasi ide-ide matematika baik secara lisan maupun visual lainnya. Dalam menyelesaikan masalah siswa gaya belajar ini juga menggunakan simbol. Hal tersebut didukung oleh Hamzah (2014) salah satu tujuan pembelajaran matematika adalah supaya siswa mampu mengkomunikasikan gagasan dengan simbol, tabel, diagram, atau media lain untuk memperjelas keadaan atau masalah.

Hasil penelitian ini berbeda dengan hasil penelitian Rizky (2018) yang menyatakan bahwa kemampuan komunikasi matematis siswa gaya belajar kinestetik memenuhi dua dari empat indikator kemampuan komunikasi matematis, dan hasil penelitian Anis Safitri (2016) yang menunjukkan bahwa siswa dengan gaya belajar kinestetik dapat memenuhi tiga dari empat indikator kemampuan komunikasi matematis. 


\section{SIMPULAN}

Berdasarkan hasil tes, observasi, wawancara, dan dokumentasi dapat diambil kesimpulan yaitu, siswa dengan gaya belajar visual dan audiotori memenuhi tiga dari empat indikator kemampuan komunikasi matematis. Gaya belajar visual dan audiotori tidak memenuhi indikator menggunakan simbolsimbol matematika dalam menyelesaikan soal. Sedangkan kemampuan komunikasi matematis siswa dengan gaya belajar kinestetik memenuhi empat dari semua indikator kemampuan komunikasi matematis.

\section{DAFTAR PUSTAKA}

Arikunto, S. (2010). Prosedur Penelitian. Jakarta: Rineka Cipta.

Asri, K., \& Permana, F. A. (2017). Peningkatan Kemampuan Komunikasi Matematis Siswa pada Materi Statistik. Jurnal Pendidikan Matematika, 9(4), 58-65.

Danaryanti, A., \& Noviani, H. (2015). Pengaruh Gaya Belajar Matematika Siswa Kelas VII terhadap Kemampuan Komunikasi Matematis di SMP. EDUMAT Jurnal Pendidikan Matematika, 3(2), 204-212.

Farihah, U. (2018). Student's Thinking Preferences in Solving Mathematics Problems Based on Learning styles: a Comparison of Paper Pencil and Geogebra. Journal of Physics: Conf. Series 1008 (2018) 012079.

Gunawan, I. (2013). Metode Penelitian Kualitatif Teori dan Praktek. Jakarta: Bumi Aksara.

Hamzah, A. (2014). Evaluasi Pembelajaran Matematika. Jakarta: PT RajaGrafindo.

Milles B. M., dkk. (2014). Qualitative Data Analysis a methods Sourcebook. United States of America.

NCTM. (2000). Principles and Standards for School Mathematics. United States of America.

Nurhidayah, D. A. (2015). Pengaruh Berprestasi Gaya Belajar terhadap Prestasi Belajar Siswa pada Mata Pelajaran Matematika SMP. Jurnal Dimensi Pendidikan dan Pembelajaran, 3(2), 13-24.

Polya, G. (2004). How to Solve it. New Jersey: Princeton University Press.

Sari, I. P. (2017). Kemampuan Komunikasi Matematika Berdasarkan Perbedaan Gaya Belajar Siswa Kelas X SMA Negeri 6 Wajo pada Materi Statistika. Jurnal Nalar Pendidikan, 5(2), 86-92.

Sugiyono. (2014). Memahami Penelitian Kualitatif. Bandung: Alfabeta.

Sugiyono. (2016). Metode Penelitian Pendekatan Kuantitatif, Kualitatif dan $R \& D$. Bandung: Alfabeta.

Vebri, N. A. (2018). Analisis Kemampuan Komunikasi Matematis Siswa dalam Menyelesaikan Permasalahan Ukuran Pemusatan Data ditinjau dari Kecerdasan Emosional. Skripsi, Diterbitkan. Universitas Negeri Jember.

Wulandari, R. (2018). Kemampuan Komunikassi Matematis Siswa Ditinjau dari Gaya Belajar dalam Menyelesaikan Sola Materi Lingkaran Kelas VIII-A MTs Assyafi'iyah Gondang Tulungagung. Skripsi. Diterbitkan. IAIN Tulungagung. 